$\begin{array}{ccc}\text { Tersedia online di: http://ejournal-balitbang.kkp.go.id/index.php/jppi } & \text { JURNAL } \\ \text { e-mail:jppi.puslitbangkan@ gmail.com } & \text { PENELITIAN } \\ \text { PERIKANAN } & \text { IDDONESIA } \\ \text { JURNALPENELITIANPERIKANANINDONESIA } & \text { Volume 23 Nomor 4 Desember 2017 } \\ \text { e-ISSN: 2502-6542 } & \\ \text { Nomor Akreditasi: 653/AU3/P2MI-LIPI/07/2015 }\end{array}$

\title{
MUSIM PENANGKAPAN DAN STRUKTUR UKURAN CAKALANG (Katsuwonus pelamis Linnaeus, 1758) DI SEKITAR RUMPON DI PERAIRAN PALABUHANRATU
}

\section{FISHING SEASON AND SIZE STRUCTURE OF SKIPJACK TUNA (Katsuwonus pelamis Linnaeus, 1758) AROUND FADs IN PALABUHANRATU WATERS}

\author{
Erfind Nurdin ${ }^{\star 1}$ dan Anthony Sisco Panggabean' \\ ${ }^{1}$ Balai Riset Perikanan Laut, Kompl. Raiser JI. Raya Bogor KM. 47 Nanggewer Mekar, Cibinong, Bogor \\ Teregistrasi I tanggal: 20 September 2017; Diterima setelah perbaikan tanggal: 03 Januari 2018;
} Disetujui terbit tanggal: 08 Januari 2018

\begin{abstract}
ABSTRAK
Sebagai alat bantu penangkapan ikan, penggunaan rumpon sekarang ini semakin meningkat dan tidak terkendali. Ketidak pastian waktu penangkapan membuat operasi penangkapan tidak efisien dengan biaya yang tinggi. Informasi musim penangkapan ikan dapat membantu untuk melakukan penangkapan ikan secara terencana dan efisien. Tujuan penelitian ini untuk menganalisis musim penangkapan ikan cakalang di perairan Palabuhanratu sehingga pemanfaatan ikan cakalang dapat dilakukan lebih efektif berdasarkan musim penangkapan dan ukuran panjang ikan yang tertangkap. Pengumpulan data ukuran panjang dan bobot cakalang dilakukan terhadap 2.580 individu. Analisa musim penangkapan dilakukan dengan metode persentase rata-rata, pola pertumbuhan berdasarkan hubungan panjang dengan berat, kapasitas fisik ikan dengan faktor kondisi (Kf). Hasil penelitian menunjukkan musim penangkapan berlangsung September sampai dengan Desember, struktur ukuran panjang antara 24 sampai dengan $60 \mathrm{cmFL}$ dengan ukuran panjang pertama kali tertangkap (Lc) sebesar $40 \mathrm{cmFL}$. Hubungan panjang dengan berat bersifat allometrik positif dan nilai rata-rata faktor kondisi (KF) sebesar 1,7 .
\end{abstract}

Kata Kunci: Cakalang; musim penangkapan; struktur ukuran; rumpon; Palabuhanratu

\begin{abstract}
As a fishing tool, the use of FADs is now increasing and uncontrollable. Uncertainty of fishing season makes fishing operations inefficient at high cost. Season fishing information can help to catch a fish in a planned and efficient manner. The purpose of this research is to analyze the skipjack fishing season in Palabuhanratu waters so that the utilization of skipjack can be done more effectively based on the catching season with the length of fish caught. The purpose of this study is to analyze the skipjack fishing season in Palabuhanratu waters so that the utilization of skipjack fish can be done more effectively based on the catching season and the length of the fish caught. Length and width of skipjack data collection were conducted on 2,580 individuals. The analysis of the fishing season was performed by means of average percentage method, growth pattern based on length and weidth relationship, physical capacity of fish with condition factor (Kf). The results showed that the fishing season begin from September until to December, the size structure of the length between 24 until $60 \mathrm{cmFL}$ with the size of length first capture (LC) is $40 \mathrm{cmFL}$. The long relationship with the weight is allometrically positive and the value of mean condition (KF) is 1.7 .
\end{abstract}

Keywords: Skipjack tuna; fishing season; size structure; fish aggregating devices; Palabuhanratu 


\section{PENDAHULUAN}

Cakalang (Katsuwonus pelamis) termasuk dalam kelompok ikan pelagis besar yang merupakan tangkapan utama di Samudra Hindia. Salah satu pusat pendaratan ikan cakalang di Jawa Barat adalah Pelabuhan Perikanan Nusantara (PPN) Palabuhanratu, Sukabumi. Kegiatan penangkapan dilakukan di perairan Selatan Jawa Barat dengan menggunakan alat bantu rumpon sebagai tempat berkumpulnya ikan.

Penggunaan alat bantu rumpon terbukti efektif dan meningkatkan efisiensi penangkapan melalui ketepatan daerah penangkapan. Pengembangan penggunaan rumpon yang terjadi saat ini diikuti dengan berkembangnya usaha penangkapan, kompetisi semakin tinggi sehingga mengakibatkan kontra produktif terhadap efisiensi penangkapan dan dapat menimbulkan dampak negatif tehadap sumber daya yang ada (Nurdin et al., 2012b).

Jumlah penggunaan rumpon sekarang ini semakin meningkat bahkan cenderung tidak terkendali. Informasi musim penangkapan ikan diharapkan dapat membantu nelayan dalam melakukan penangkapan ikan secara lebih terencana dan efisien. Penangkapan dapat dilakukan lebih intensif dengan mengatur jumlah armada tangkap pada bulan-bulan musim tangkap. Namun dibutuhkan kesadaran nelayan dan kebijakan pemerintah untuk memperhatikan jumlah armada penangkap ikan yang beroperasi, agar tidak terjadi tangkapan berlebih (overfishing).

Tidak pastinya waktu penangkapan ikan dapat menyebabkan operasi penangkapan tidak efisien dengan biaya yang tinggi. Pengetahuan nelayan mengenai musim penangkapan ikan diharapkan mampu mengurangi beban biaya operasional dengan penentuan waktu yang lebih baik sebelum melaut (Nurdin et al., 2012a).

Pemanfaatan sumber daya tuna di Palabuhanratu menggunakan kapal berukuran dibawah 10 GT yang mengoperasikan lima jenis pancing yaitu pancing tonda (troll line), pancing tomba (floating line), pancing layang-layang (kite line), pancing coping (hand line) dan pancing taber (vertical line) (Nurdin et al., 2015). Kelima jenis pancing ini dioperasikan di sekitar rumpon untuk menangkap ikan tuna termasuk ikan cakalang, namun jenis pancing yang paling banyak dioperasikan oleh nelayan adalah pancing tonda, coping dan taber.
Penelitian ini bertujuan agar pemanfaatan ikan cakalang dapat dilakukan lebih efektif berdasarkan musim penangkapan dengan memperhatikan sebaran ukuran panjang biologis hasil tangkapan.

\section{BAHAN DAN METODE}

Penelitian dilakukan di Palabuhanratu, mulai Januari sampai dengan November 2016. Pengumpulan data ukuran panjang dan bobot ikan cakalang hasil tangkapan armada tonda di sekitar rumpon dilakukan dengan bantuan enumerator di PPN Palabuhanratu (PPNP) Jawa Barat. Pengukuran panjang cagak (fork length, FL) dilakukan tanpa membedakan jenis kelamin, menggunakan meteran gulung dengan panjang maksimum 5 meter dengan ketelitian $1 \mathrm{~mm}$. Bobot ikan diukur menggunakan timbangan berkapasitas $10 \mathrm{~kg}$ dengan ketelitian $1 \mathrm{gram}$. Jumlah sampel ikan cakalang (Katsuwonus pelamis) yang diamati sebanyak 2.580 ekor dengan rata-rata pengambilan sampel per bulan sebanyak 235 ekor (11 bulan).

Pendugaan pola musim penangkapan ikan dapat diperoleh dari data hasil tangkapan per bulan. Analisis dilakukan dengan cara mencari rata-rata data bulanan (produksi dan upaya) selama beberapa tahun. Nilai tertinggi dijadikan dugaan sebagai musim penangkapan, sedangkan nilai terendah bukan musim penangkapan (Merta et al., 2004).

Analisis pola musim penangkapan ikan menggunakan metode persentase rata-rata (the average percentage methods) yang didasarkan pada analisis runtun waktu (times series analysis) (Spiegel, 1961).

Langkah pertama, dilakukan penghitungan nilai hasil tangkapan per upaya tangkap (CPUE = Catch Per Unit Effort $=\mathrm{U})$ per bulan $\left(\mathrm{U}_{\mathrm{i}}\right)$ dan rata-rata bulanan CPUE dalam setahun $(\bar{U})$ dengan rumus:

$\bar{U}=\frac{1}{m} \sum_{i=1}^{m} U_{i}$

di mana;

$=$ CPUE rata-rata bulanan dalam setahun (ton/ $\bar{U} \quad$ trip)

$=$ CPUE per bulan (ton/trip)

$\psi_{\mathrm{m}}=12$ (jumlah bulan dalam setahun)

Selanjutnya menghitung nilai $U_{p}$ yaitu rasio $U_{i}$ terhadap $\bar{U}$ dinyatakan dalam persen: 
$U_{p}=\frac{U_{i}}{\bar{U}} \times 100 \%$

$\operatorname{Im}_{i}=\frac{1}{t} \sum_{i=1}^{t} U$

di mana;

$\mathrm{IM}_{\mathrm{i}}=$ Indeks Musim ke $\mathrm{i}$

$\mathrm{t}=$ Jumlah tahun dari data

Bila jumlah $\mathrm{IM}_{\mathrm{i}}$ tidak sama dengan $1.200 \%$ (12 bulan $\times 100 \%$ ), maka diperlukan penyesuaian dengan rumus (3):

$I M S_{i}=\frac{1200}{\sum_{i=1}^{m} I M_{i}} \times \mathrm{IM}_{\mathrm{i}}$

di mana;

$\mathrm{IMS}_{\mathrm{i}}=$ Indeks Musim ke i yang disesuaikan

Bila dalam perhitungan ada nilai ekstrim pada $U_{\text {, }}$, maka nilai $U_{p}$ tidak digunakan dalam perhitungan Indeks Musim (IM), yang digunakan adalah median (Md) dari IM tersebut. Jika jumlah nilai Md tidak sebesar $1.200 \%$, maka perlu dilakukan penyesuaian sebagai berikut:

$$
I M M d S i=\frac{1200}{\sum_{i=1}^{m} M d_{i}} \times M_{\mathrm{i}}
$$

di mana;

$\mathrm{IMMdS}_{\mathrm{i}}=$ Indeks Musim dengan Median yang disesuaikan ke i.

Selanjutnya penentuan musim ikan jika indeks musim (IM) lebih dari 1 (lebih dari $100 \%$ ), dan bukan musim jika IM kurang dari 1 (kurang dari $100 \%$ ). Apabila IM = $1(100 \%)$, dikatakan dalam keadaan normal atau berimbang.

Hubungan panjang - bobot dianalisis dengan model pertumbuhan menurut Bal \& Rao (1984) menggunakan persamaan:

$\mathrm{W}=a \mathrm{~L}^{\mathrm{b}}$

di mana;

$\mathrm{W} \quad=$ bobot individu $(\mathrm{kg})$

$\mathrm{L} \quad=$ panjang karapas udang $(\mathrm{cm})$

a dan $b=$ konstanta hasil regresi

Nilai b sebagai penduga hubungan antara panjang dan bobot dengan kriteria:
Nilai $b=3$, ikan memiliki pola pertumbuhan isometrik (pertambahan bobot seimbang dengan pertambahan panjang)

Nilai $b>3$, ikan memiliki pola pertumbuhan alometrik positif (pertambahan bobot lebih besar dari pertambahan panjang).

Nilai $b<3$, ikan memiliki pola pertumbuhan alometrik negatif (pertambahan bobot lebih kecil dari pertambahan panjang).

Nilai b diuji untuk mengetahui apakah nilai b yang diperoleh berbeda nyata dengan nilai $b=3$ menggunakan uji-t pada tingkat kepercayaan 95\% (Steell \& Torrie, 1989).

Pendugaan nilai tertangkap (length at capture/LC) dilakukan dengan pendekatan fungsi logistik (King, 2007). Analisis faktor kondisi $\left(\mathrm{K}_{\mathrm{F}}\right)$ dari ukuran panjang cagak (FL) dilakukan untuk menunjukkan keadaan baik dari ikan dilihat dari kapasitas fisik survival dan reproduksi. Secara komersial kondisi ini mempunyai arti kualitas dan kuantitas daging yang tersedia. Nilai $\mathrm{K}$ berkisar $2-4$ bila badan ikan pipih, dan $1-3$ bila badan ikan tidak pipih (fusiform). (Effendie, 2002).

$\mathrm{K}_{\mathrm{F}}=10^{2} \mathrm{~W} / \mathrm{L}^{3}$

di mana;

$\mathrm{W}=$ bobot $(\mathrm{kg})$

$\mathrm{L}=$ panjang $(\mathrm{cm})$

\section{HASIL DAN BAHASAN \\ Hasil}

\section{Musim Penangkapan}

Pendugaan indeks musim penangkapan perbulan selama periode 2010-2016 menunjukkan bahwa musim penangkapan ikan terjadi pada September sampai Desember dengan nilai indeks diatas nilai 100 dengan puncak musim terjadi pada September (Gambar 1).

\section{Distribusi Ukuran Panjang}

Ikan cakalang yang berhasil diukur selama penelitian periode Januari - November sebanyak 2.580 ekor. Distribusi nilai tengah (mid length) ukuran panjang cagak (FL) berkisar antara $26-62 \mathrm{cmFL}$ dengan panjang rata-rata $40 \mathrm{~cm}( \pm 5)($ Tabel 1$)$.

Pada Gambar 2 mempresentasikan modus ukuran panjang yang mencerminkan kelompok cakalang yang tertangkap. Puncak modus secara keseluruhan individu menunjukkan bahwa ukuran dominan 
tertangkap sekitar $42 \mathrm{~cm}$ (mid length) dengan persentase sebesar $38,64 \%$, berdasarkan hasil tangkapan bulanan terlihat bahwa persentase terbesar yaitu $50,9 \%$ pada Maret.

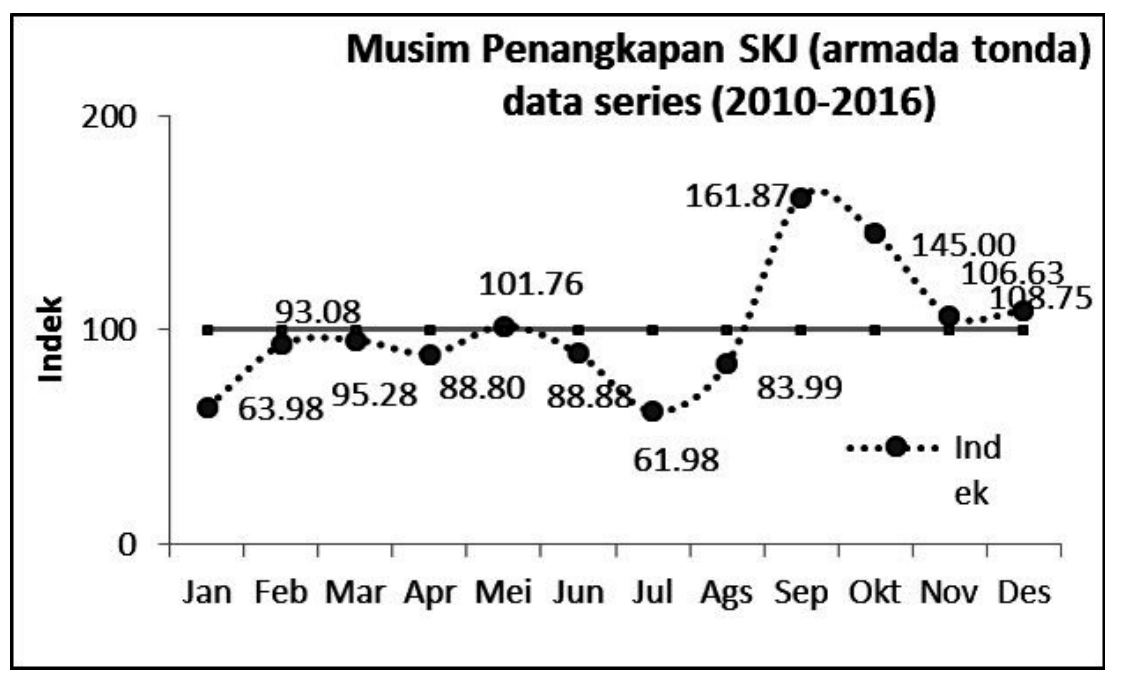

Gambar 1. Indeks musim penangkapan ikan cakalang tertangkap tonda di Palabuhanratu.

Figure 1. Seasonal fishing index for skipjack caught by trolling line at Palabuhanratu.

Tabel 1. Ukuran panjang cagak cakalang hasil tangkapan di sekitar rumpon yang didaratkan di PPN Palabuhanratu (Januari - November 2016)

Table 1. Fork Length of skipjack tuna caught around of FADs landed at Palabuhanratu fishing port (January-November 2016)

\begin{tabular}{ccccc}
\hline \multirow{2}{*}{ Bulan } & \multirow{2}{*}{ Ind $(\mathbf{n})$} & \multicolumn{3}{c}{ Ukuran Panjang Cagak /FL (Cm) } \\
\cline { 3 - 5 } & 224 & Min & Maks & Rata-rata \\
\hline Januari & 34 & 54 & 42,3 \\
Februari & 264 & 26 & 54 & 41,0 \\
Maret & 283 & 30 & 50 & 40,8 \\
April & 262 & 30 & 50 & 39,6 \\
Mei & 150 & 30 & 58 & 37,4 \\
Juni & 155 & 26 & 62 & 35,3 \\
Juli & 196 & 30 & 50 & 39,1 \\
Agustus & 234 & 30 & 54 & 40,4 \\
September & 201 & 34 & 54 & 40,7 \\
Oktober & 267 & 30 & 58 & 41,1 \\
Nopember & 344 & 26 & 54 & 40,0 \\
Total & 2580 & 26 & 62 & 40 \\
\hline
\end{tabular}




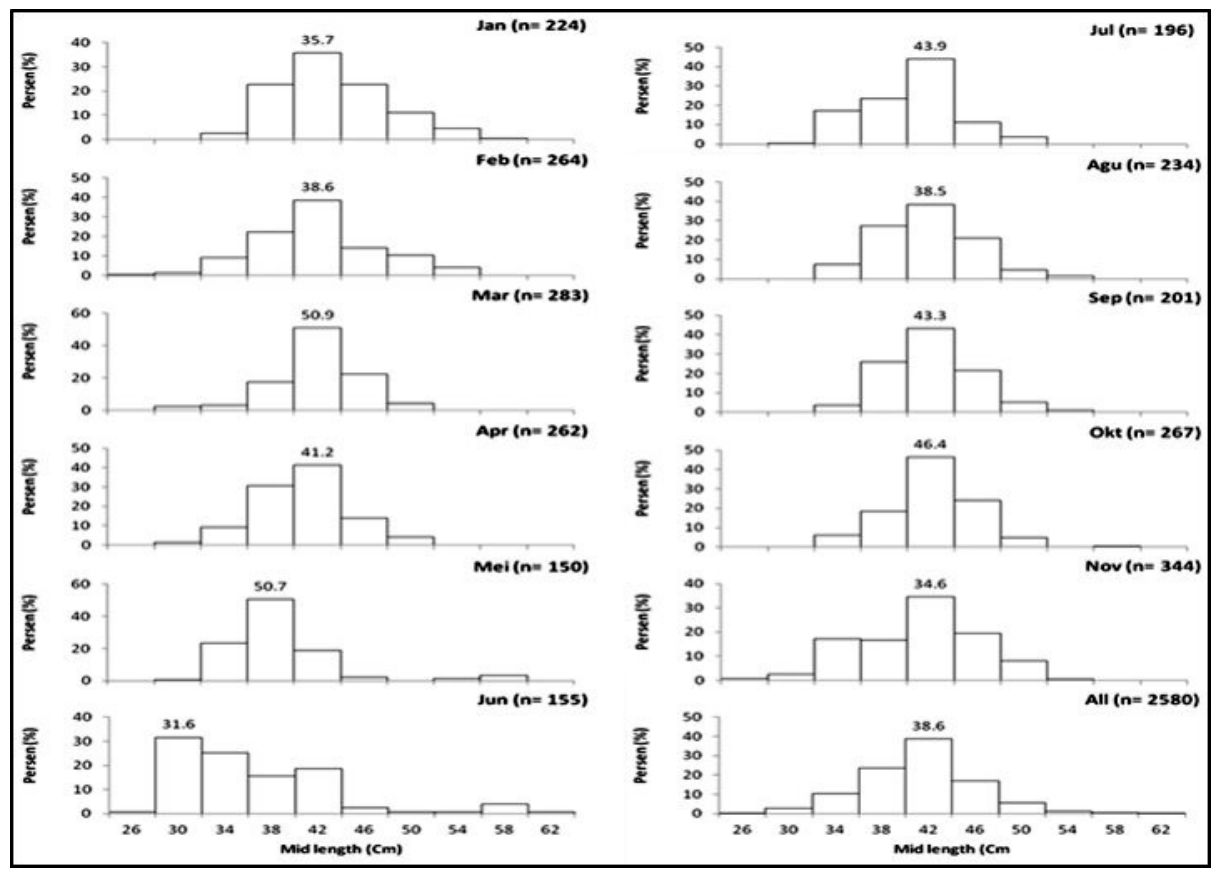

Gambar 2. Distribusi frekwensi panjang cagak cakalang hasil tangkapan di sekitar rumpon yang didaratkan di PPN Palabuhanratu (Januari - November 2016).

Figure 2. Length frequency distribution of skipjack tuna caught around of FADs landed at PPN Palabuhanratu (January-November 2016).

Hasil perhitungan menunjukkan bahwa ukuran panjang pertama kali tertangkap ikan cakalang yang

didaratkan di PPN Palabuhanratu oleh armada tonda di sekitar rumpon berukuran $40 \mathrm{cmFL}$ (Gambar 3).

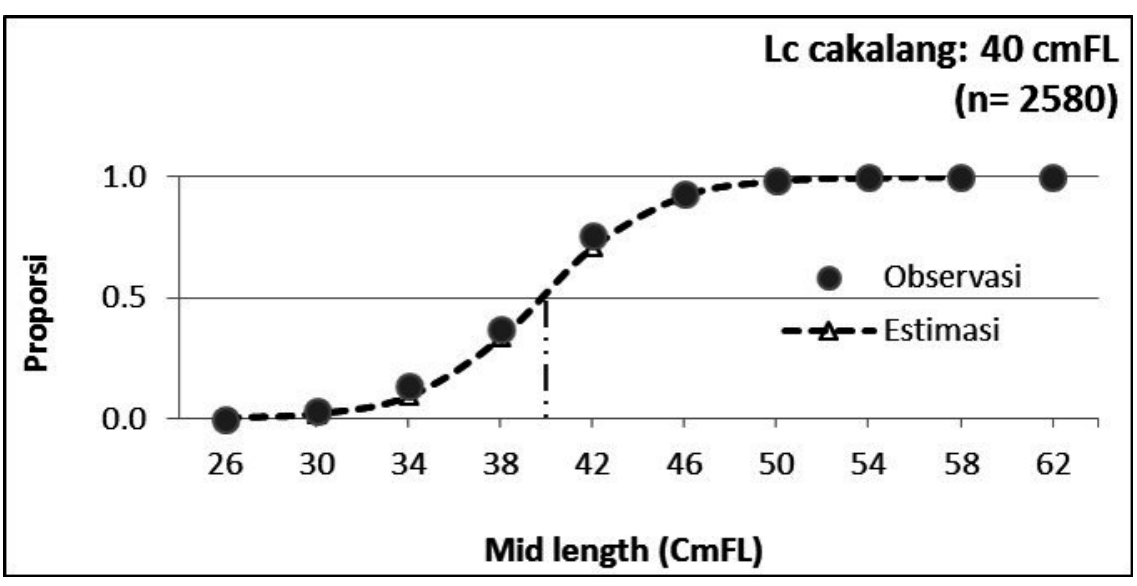

Gambar 3. Ukuran pertama kali tertangkap ikan cakalang hasil tangkapan di sekitar rumpon yang didaratkan di PPN Palabuhanratu (Januari - November 2016).

Figure 3. Length at first capture of skipjack tuna caught around of FADs landed at PPN Palabuhanratu (January-November 2016).

\section{Hubungan Panjang dengan Bobot}

Salah satu kegunaan analisis regresi antara panjang dan bobot adalah untuk memprediksi bobot ikan berdasarkan ukuran panjang ikan. Hasil penelitian ikan cakalang yang didaratkan di PPN Palabuhanratu diperoleh persamaan $\mathrm{W}=0,011 \mathrm{~L}^{3.115}, \mathrm{R}^{2}=0,921$, dengan nilai koefisien regresi $(r)=0,952$ (Gambar 4).
Sampel ikan yang digunakan tidak membedakan jenis kelamin. Untuk mengetahui pola pertumbuhan hubungan panjang dengan bobot ikan maka dilakukan Uji-tterhadap nilaib pada selang kepercayaan $95 \%(a ́=0,05)$ diperoleh nilai $b=3,115(b>3)$. Hasil ini menandakan bahwa pola pertumbuhan ikan cakalang hasil tangkapan di sekitar rumpon yang didaratkan di PPN Palabuhanratu bersifat allometrik positif, dimana pertambahan bobot lebih cepat daripada pertambahan panjang. 


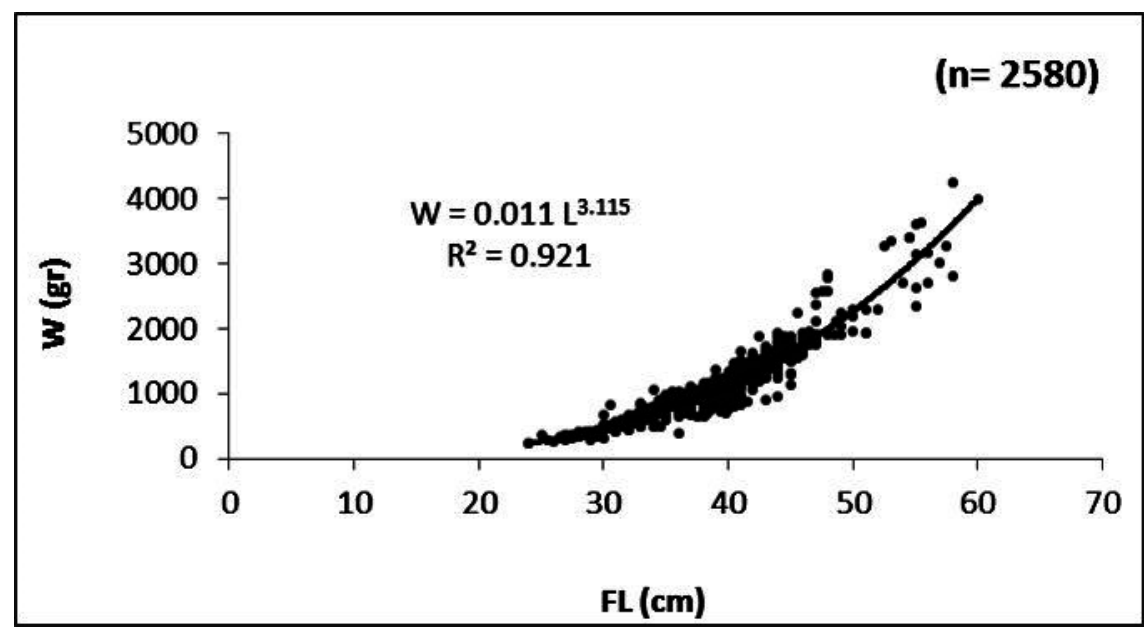

Gambar 4. Hubungan panjang cagak dan bobot cakalang hasil tangkapan di sekitar rumpon yang didaratkan di PPN Palabuhanratu (Januari-November 2016).

Figure 4. Length and weight relationship of skipjack tuna caught around of FADs was landed at PPN Palabuhanratu (January - November 2016).

\section{Faktor Kondisi $\left(\mathrm{K}_{\mathrm{F}}\right)$}

Analisis faktor kondisi $\left(\mathrm{K}_{\mathrm{f}}\right)$ dilakukan untuk melihat keadaan ikan dari kapasitas fisiknya. Pengamatan faktor kondisi $\left(\mathrm{K}_{\mathrm{f}}\right)$ terhadap sampel ikan diperoleh nilai rata-rata faktor kondisi ikan cakalang sebesar 1,7 dengan kisaran1,1 - 2,9 (Tabel 2). Mengacu pada Effendie (2002) hasil ini menandakan ikan cakalang tersebut masih berada pada batas ambang kondisi yang baik dengan kisaran nilai $\left(\mathrm{K}_{\mathrm{F}}\right)$ antara 1-3.

Tabel2. Faktor kondisi $\left(\mathrm{K}_{\mathrm{f}}\right)$ hasil tangkapan cakalang di sekitar rumpon yang didaratkan di PPN Palabuhanratu (Januari-November 2016)

Table 2. Condition factor of skipjack tuna caught around of FADs landed at PPN Palabuhanratu (January -November 2016)

\begin{tabular}{cccc}
\hline Sample $(\mathbf{n}=\mathbf{2 5 8 0})$ & FL $(\mathbf{c m})$ & $\mathbf{W}$ (gram) & $\mathbf{K}_{\mathbf{F}}$ \\
\hline Min & 24,0 & 226,0 & 1,1 \\
Max & 60,0 & $4.255,0$ & 2,9 \\
Rata-rata & 39,6 & $1.115,9$ & 1,7 \\
SD & 4,8 & 432,8 & 0,1 \\
\hline
\end{tabular}

\section{Bahasan}

\section{Musim Penangkapan}

Penggunaan alat bantu pengumpul ikan seperti rumpon banyak ditemukan pada perikanan tuna skala kecil. Rumpon terbukti dapat meningkatkan efisiensi penangkapan melalui ketepatan daerah penangkapan. Pengembangan penggunaan rumpon yang terjadi saat ini diikuti dengan berkembangnya usaha penangkapan tuna dengan menggunakan berbagai jenis alat tangkap. Saat ini kompetisi antara unit penangkapan ikan dalam penggunaan rumpon semakin tinggi sehingga mengakibatkan kontra produktif terhadap efisiensi penangkapan dan dapat menimbulkan dampak negatif tehadap sumber daya yang ada (Nurdin et al., 2012b).

Efisiensi penggunaan rumpon saat ini sudah menurun, diduga hal ini disebabkan oleh kondisi penggunaan rumpon yang sekarang ini semakin meningkat bahkan cenderung tidak terkendali. Dengan mengetahui informasi musim penangkapan ikan, diharapkan dapat membantu para nelayan dalam melakukan penangkapan ikan secara lebih terencana dan efisien. Nelayan dapat menangkap secara lebih intensif dan mengatur jumlah armada tangkap pada bulan-bulan musim tangkap. Namun demikian, dalam hal ini dibutuhkan kesadaran nelayan dan kebijakan pemerintah untuk memperhatikan jumlah armada penangkap ikan yang beroperasi, jangan sampai terjadi tangkapan berlebih (overfishing).

Pada penelitian ini musim penangkapan ikan terjadi pada September sampai Desember (musim peralihan II) dengan puncak musim pada September. Merta et al., (2004) menyatakan bahwa di perairan barat Sumatera puncak musim penangkapan dengan alat tangkap tonda terjadi pada Oktober di 
Palabuhanratu dengan alat tangkap jaring insang berlangsung pada Juli - Oktober dengan puncak musim pada September di Cilacap dengan alat tangkap tonda dan jaring insang berlangsung pada Juni sampai Oktober dengan puncak musim pada September.

Nurdin \& Nugraha (2008) menyatakan bahwa musim penangkapan tuna cakalang hasil tangkapan pancing ulur di Sendang biru Malang terjadi antara Mei hingga Oktober dengan puncak musim pada September. Musim penangkapan cakalang di perairan Manado terjadi pada April hingga November dengan puncak musim pada September (Kekenusa et al., 2012). Begitu pula di perairan Sangihe, musim penangkapan terjadi pada April hingga Oktober dengan puncaknya pada September (Paendong et al., 2014).

Salah satu penentu kesuburan perairan yang dapat berpengaruh terhadap produksi dan musim penangkapan ikan adalah terjadinya upwelling. Nontji (1987) menyatakan bahwa upwelling berskala besar terjadi di perairan Selatan Jawa. Upwelling di perairan Indonesia bersifat musiman yang terjadi pada musim timur (Mei-September), hal ini mengindikasikan adanya hubungan antara upwelling dan kesuburan perairan sehingga diduga banyak tersedia makanan untuk ikan pada bulan-bulan tersebut.

\section{Struktur Ukuran Ikan}

Hasil penelitian ini hampir sama dengan penelitian Fathur et al. (2015) di perairan selatan Jawa (Cilacap, Palabuhanratu, Tamperan-Pacitan, dan Sendang biruMalang) yang dilakukan terhadap 3.118 ekor ikan dengan kisaran panjang cagak antara 20-65 cmFL, diperoleh nilai panjang pertama kali tertangkap (LC), sebesar 38,73 cmFL. Hasil penelitian Nugraha et al.,(2010) di Tulehu, Ambon pada Maret sampai Desember 2007, diperoleh panjang cagak berkisar antara 30-78 cmFL dengan nilai Lc 41,7 cmFL.

Wang et al. (2012) menyatakan bahwa data yang dikumpulkan observer di Western and Central Pacific Ocean pada April 2004 hingga Mai 2011 (WCPO) dari 3.831 sampel hasil tangkapan di sekitar rumpon (floating object) berkisar antara 26,4-73,3 cmFL dengan ukuran rata-rata $43,3 \mathrm{cmFL}$.

Terdapat beberapa hasil penelitian tentang ukuran pertama kali matang gonad (Lm) ikan cakalang dengan hasil yang bervariasi. Penelitian Grande et al., (2010) menunjukkan bahwa nilai Lm ikan cakalang di Samudera Hindia bagian barat sebesar $37.8 \mathrm{cmFL}$. Menurut Jatmiko et al., (2015) di Samudera Hindia bagian timur, nilai Lm yang diperoleh sebesar 42,9
cmFL. Menurut Nikijuluw (2009) di Perairan Samudera Hindia untuk panjang pertama kali matang gonad ( $\mathrm{Lm}$ ) ikan cakalang berkisar antara $41-43 \mathrm{~cm}$.

Jamal et al., (2011) melaporkan bahwa Lm cakalang yang tertangkap di Teluk Bone sebesar 46,5 $\mathrm{cm}$. Froese \& Pauly (2011) menerangkan bahwa Lm cakalang sebesar $40 \mathrm{~cm}$ pada kisaran antara 40-45 $\mathrm{cmFL}$. Merujuk pada beberapa hasil penelitian terdahulu menunjukkan ikan cakalang yang tertangkap masih dapat dikatakan layak tangkap.

Seperti yang dinyatakan oleh Udupa (1986), bahwa perbedaan ukuran pertama kali matang gonad tersebut dapat terjadi dengan nilai Lm yang bervariasi. Individu yang berasal dari satu kelas umur atau kelas panjang yang sama, tidak harus selalu mencapai panjang pertama kali matang gonad pada ukuran yang sama. Hal ini dipengaruhi oleh kondisi lingkungannya.

\section{Hubungan Panjang dengan Bobot}

Hubungan panjang dengan bobot diperoleh nilai $b=3,115(b>3)$, yang menandakan pola pertumbuhan ikan cakalang hasil tangkapan di sekitar rumpon yang didaratkan di PPN Palabuhanratu bersifat allometrik positif. Hasil ini sama dengan beberapa penelitian lain di Bitung Sulawesi Utara dengan nilai b sebesar 3,332 (Nugraha \& Mardlijah, 2008). Hasil penelitian Jin et al., (2014) menggunakan data tahun 2013, 2012 dan 2009 di Western and Central Pacific untuk ukuran ikan cakalang dibawah $60 \mathrm{~cm}$ bersifat allometrik positif dengan nilai b sebesar $3,367,3,234$ dan 3,300. Sebagai pembanding dari negara lain disajikan dalam Tabel 4 .

Hasil ini berbeda dengan penelitian Nurdin et al., (2012a) di Perairan Prigi Jawa Timur dengan nilai b sebesar 2,733 dan Nugraha et al., (2010) di Laut Banda sebesar 2,751. Jamal et al., (2011) menyatakan bahwa di perairan Teluk Bone menunjukkan nilai $b$ yang juga berbeda dengan membagi berdasarkan zona utara sebesar 2,505, tengah 2,599 dan selatan 2,773.

Terjadinya variasi hubungan panjang bobot ikan dipengaruhi oleh habitat, lingkungan, musim, sumber makanan, tingkat kematangan gonad, kesuburan perairan, kesehatan, umur, jenis kelaminserta pengaruh intensitas penangkapan ikan terhadap populasi (Hossain, 2010; Jamal et al., 2011). King (2007) menyatakan bahwa hubungan panjang bobot dapat digunakan untuk menentukan kemungkinan perbedaan antara jenis ikan yang sama pada stok yang berbeda. 
Tabel 4. Hubungan panjang bobot ikan cakalang di beberapa lokasi berbeda

Table 4. Length weight relationships of skipjack in several different sites

\begin{tabular}{lrrrrr}
\hline \multicolumn{1}{c}{ Lokasi Perairan } & a & b & Sex & $\begin{array}{c}\text { Tipe } \\
\text { panjang }\end{array}$ & n \\
\hline Brazil (Southern region, Santa & & & & & \\
Catarina, 1995-1996) & 0,00654 & 3,293 & Unsexed & FL & 2.029 \\
Cuba (West zone) & 0,00878 & 3,22 & unsexed & FL & 1.612 \\
Eastern Atlantic & 0,00561 & 3,315 & Unsexed & FL & 2.554 \\
Eastern tropical Pacific & 0,00403 & 3,413 & Unsexed & FL & 924 \\
Hawaii & 0,00481 & 3,368 & Unsexed & FL & 1.298 \\
Madagascar & 0,0113 & 3,16 & Mixed & FL & 848 \\
New Zealand & 0,06776 & 3,29 & Unsexed & FL & 120 \\
Philippines (Davao Gulf, 2009- & 0,01482 & 3,096 & Male & SL & 189 \\
2012) & 0,00859 & 3,229 & unsexed & & \\
Somalia (Western Indian Ocean) & 0,00452 & 3,379 & unsexed & & \\
South Africa (Eastern Cape) & 0,00481 & 3,35 & unsexed & FL & 664 \\
USA (North and South Carolina) & 0,00577 & 3,353 & Unsexed & FL & 644 \\
Western Atlantic & & & & & \\
\hline
\end{tabular}

Sumber: Fishbase, update ver. 06/2017

Faktor Kondisi $\left(K_{F}\right)$

Pengamatan faktor kondisi $\left(\mathrm{K}_{\mathrm{F}}\right)$ terhadap sampel ikan diperoleh nilai rata-rata faktor kondisi ikan cakalang sebesar 1,7 dengan kisaran 1,1 - 2,9. Nurdin et al., (2012a) menyatakan bahwa rata-rata faktor kondisi ikan cakalang yang didaratkan di PPN Prigi sebesar 2,08 dengan kisaran 1,4 - 2,7. Menurut Effendie (2002), hasil ini menandakan ikan tersebut masih berada pada batas ambang kondisi yang baik dengan kisaran nilai $\left(\mathrm{K}_{\mathrm{F}}\right)$ antara 1-3.

Lebih lanjut, Effendie (2002) menyatakan bahwa faktor kondisi $\left(K_{F}\right)$ merupakan derivat dari pertumbuhan. Faktor kondisi menunjukkan kondisi baik fisiologis ikan dilihat dari kapasitas fisik survival dan reproduksi. Secara komersial kondisi ini mempunyai arti kualitas dan kuantitas daging yang tersedia.Variasi nilai $\mathrm{K}_{\mathrm{F}}$ tergantung pada ketersediaan makanan, umur, jenis kelamin dan kematangan gonad. Hossain (2010) menyatakan bahwa faktor kondisi merupakan indikator ketersediaan makanan di wilayah perairan dan secara umum siklus perubahan musim dapat mempengaruhi perkembangan gonad.

\section{KESIMPULAN}

Musim penangkapan cakalang di Palabuhanratu terjadi pada September - Desember dengan puncak musim pada September. Rata-rata ukuran panjang pertama kali tertangkap (LC) mencapai $40 \mathrm{cmFL}$, pola pertumbuhan bersifat alometrik positif dengan kondisi fisiologi yang baik. Dari hasil penelitian ini disarankan agar penangkapan ikan cakalang sebaiknya diarahkan pada waktu musim penangkapan ikan dengan memperhatikan kondisi ukuran ikan dewasa sehingga pemanfaatan ikan cakalang dapat dilakukan dengan optimal dan berkelanjutan.

\section{PERSANTUNAN}

Tulisan ini merupakan kontribusi dari kegiatan hasil riset Karakteristik Biologi Perikanan Habitat Sumberdaya dan Potensi Produksi Sumberdaya Ikan di WPP 573 (Samudera Hindia Selatan Jawa) T.A. 2016 di Balai Riset Perikanan Laut - Muara Baru, Jakarta. Ucapan terima kasih disampaikan kepada staf PPN Palabuhanratu yang membantu pengumpulan data dilapangan.

\section{DAFTAR PUSTAKA}

Bal, D.V. \& Rao, K.V. (1984). Marine Fisheries (p. 524). NewDelhi : Tata Mc.Graw-Hill Publishing CompanyLimited.

Effendie, M.I. (2002). Biologi Perikanan (p. 163). Yayasan Pustaka Nusatama. Yogyakarta. 
Fathur, R., Nugraha, B., \& Wudji, A. (2015). Pendugaan parameter populasi ikan cakalang (Katsuwonus pelamis, Linnaeus, 1758) di Samudera Hindia Selatan. Bawal. 7 (2), 77-85.

Froese, R. \& Pauly, D. (2011). Fish Base (update ver. 06/2017). World Wide Web Electronic Publication, www.fishbase.org.

Grande, M., Murua, H., Zudaire, I. \& Korta, M. (2010). Spawning activity and batch fecundity of skipjack (Katsuwonus pelamis) in The Western Indian Ocean. IOTC-2010-WPTT-47, 28 pp.

Hossain, Y. (2010). Length-weight, length-length relationship and condition factors of three schibid Catfish from The Padma River, Northwestern Bangladesh. Asian Fisheries Science. (23), 329339.

Jatmiko, I., Hartaty, H., \& Bahtiar, A. (2015). Biologi reproduksi ikan Cakalang (Katsuwonus pelamis) di Samudera Hindia Bagian Timur. Bawal. 7 (2), 87-94.

Jamal, M., Sondita, M.F.A., Haluan, J. \& Wiryawan, B. (2011). Pemanfaatan data biologi ikan Cakalang (Katsuwonus pelamis) dalam rangka pengelolaan perikanan bertanggung jawab di Perairan Teluk Bone. Jurnal Natural Indonesia. 14 (1), 107-113.

Jin, S., Yan, X., \& Fan, H. Z. W. (2014) .Weightlength relationships and Fulton'scondition factors of skipjack tuna (Katsuwonus pelamis) in the western and central Pacific Ocean. Peer J. 3:e758. 12 p.

Kekenusa, J. S., Watung, V.N.R., \& Hatidja, D. (2012). Analisis penentuan musim penangkapan ikan cakalang (Katsuwonus pelamis) di Perairan Manado Sulawesi Utara. Jurnal IImiah Sains.(12). 2, 112-119.

King, M. (2007). Fisheries biology, assessment and management (p.381) Second edition. Blackwell Sciencetific Publication, Oxford.

Merta, I. G.S., Iskandar, B., \& Bahar, S. (2004). Musim Penangkapan Ikan Pelagis Besar di Indonesia ( $p$. 116). Balai Riset Perikanan Laut. Pusat Riset Perikanan Tangkap. Badan Riset Kelautan dan Perikanan. Departemen Kelautan dan Perikanan. Jakarta.
Nikijuluw, V.P.H. (2009). Status sumber daya ikan tuna Samudera Hindia: Implikasinya bagi Indonesia. J.Kebijak.Perik.Ind 1(1), 32-44.

Nontji, A. (1987). Laut Nusantara (p. 368). Penerbit Djambatan Jakarta.

Nugraha, B. \& Mardlijah, S. (2008). Beberapa aspek biologi cakalang (Katsuwonus pelamis) yang didaratkan di Bitung, Sulawesi Utara. Bawal. 2(1), $45-50$.

Nugraha, B., Mardlijah, S. \& Rahmat, E. (2010). Komposisi ukuran cakalang (Katsuwonus pelamis) hasil tangkapan huhate yang didaratkan di Tulehu Ambon. Bawal. 3 (3), 199 -207.

Nurdin, E., \& Nugraha, B. (2008). Penangkapan tuna dan cakalang dengan menggunakan alat tangkap pancing ulur (Hand Line) yang berbasis di pangkalan pendaratan ikan Pondokdadap Sendang Biru, Malang. BAWAL. (2).1, 27 - 33

Nurdin, E., Taurusman, A.A. \& Yusfiandayani, R. (2012a). Struktur ukuran, hubungan panjang-bobot dan faktor kondisi ikan tuna di Perairan Prigi, Jawa Timur. Bawal. 4 (2), 67-73.

Nurdin, E., Taurusman, A. A. \& Yusfiandayani, R. (2012b). Optimasi jumlah rumpon, unit armada dan musim penangkapan perikanan tuna Di Perairan Prigi, Jawa Timur. J. Lit. Perikan. Ind. (18) 1: 5360

Nurdin. E., Sondita, M.F.A., Yusfiandayani, R., \& Baskoro, M. (2015). Produktivitas dan musim penangkapan ikan madidihang (Thunnus albacares Bonnaterre,1788) pada perikanan skala kecil di Palabuhanratu, Jawa Barat. J.Lit.Perikan.Ind. 21(3), 147-154.

Paendong, M. S., Kekenusa, J. S., \& Weku, W.C.D. (2014). Analisis penentuan musim penangkapan ikan Cakalang (Katsuwonuspelamis L) di Perairan Sangihe Sulawesi Utara. Jurnal de Caetesian JdC. 3(2), 36-41.

Steell, R. G. H., \& Torrie, J. S .H. (1989). Prinsip dan Prosedur Statistika: Suatu Pendekatan Biometrik (p. 748). Edisi kedua. Gramedia. Jakarta.

Spiegel, M. R. (1961). Theory and problems of Statistics (p. 359) New York : Schaum Publ. Co. 
Udupa, K.S. (1986). Statistical method of estimating the size at first maturity in fishes. ICLARM. Metro Manila. Fishbyte. 4 (2), 8-10.
Wang, X., L. Xu, Chen, Y., Zhu, G., Tian, S. \& Zhu, J. (2012). Impacts of fish aggregation devices on size structures of Skipjack Tuna (Katsuwonus pelamis). Aquatic Ecology, Springer. 13 p. 